\title{
Local Content in English Textbook of Elementary School in Surakarta (Content Analysis)
}

\author{
Honest Ummi Kaltsum and Susiati \\ Universitas Muhammadiyah Surakarta, Surakarta
}

\section{Abstract}

English in elementary school is categorized as a local content curriculum area. Local content should contain local potentials where English is taught therefore the textbook content must have its own distinctive regional characteristics. Through some observations it is found that English textbooks for primary school in Surakarta have not fully accommodated the local content. Most of the textbooks contain general discourse and do not have specific characteristics and potential areas where English is taught. This paper aims to describe how far English textbook for elementary school in Surakarta accommodates its local content using content analysis. The finding shows that the local

Corresponding Author: Honest Ummi Kaltsum huk172@ums.ac.id

Received: 23 January 2019 Accepted: 26 February 2019 Published: 17 March 2019

Publishing services provided by Knowledge E

(c) Honest Ummi Kaltsum and Susiati. This article is distributed under the terms of the Creative Commons Attribution License, which permits unrestricted use and redistribution provided that the original author and source are credited.

Selection and Peer-review under the responsibility of the International Seminar on Language, Education, and Culture Conference Committee. content is not spread in all skills, and can only be found in 8 skills from total 56 skills, or it is about $14 \%$.

English in elementary school is categorized as a local content curriculum area. Local content should contain local potentials for any course taught, including English. Therefore, the textbook content must have its own distinctive regional characteristics. Through some observations conducted, it is found that English textbooks for primary school in Surakarta have not fully accommodated the local content. Most of the textbooks contain general discourse and do not have specific characteristics and potential areas where English is taught. This paper aims to describe how far English textbook for elementary school in Surakarta accommodates its local content by employing a content analysis approach.

Keywords: local content, elementary English, content analysis

\section{Introduction}

The government stipulates that English for Elementary Education (EE) as local content subjects. Local content is an educational program whose content and media delivery are related to the physical, social, and cultural environment as well as regional development needs that need to be taught to students. The main purpose of local content is to develop the potential of students in accordance with regional characteristics and potential. Through observation of several elementary school English textbooks, it was found 
that the material or content of the book had not met local content standards in the sense that the textbooks did not represent actual local content, but contained general and not specific discourses about the peculiarities of the areas where English was studied. This is an interesting problem given that there is a gap between government policies and actual conditions. The same statement is also written by Suyanto in Sutiyono (2014: 7) It is said that English teaching materials for elementary schools are quite a lot on the market, but not many meet the requirements to be used as student handbooks in class. Therefore, the teacher must be able and skilful in choosing a book by considering suitability with the goals, content, language, and level of difficulty for students..

This study aims to analyse how good local content conveyed in elementary school English textbooks in Surakarta. Based on the background above, this study focuses on analysing the local content in English textbook for elementary school. Textbooks are the main learning resources for achieving basic competencies and core competencies and declared feasible by the Ministry of Education and Culture for use in education units (Permendikbud 2016 Number 008). Textbooks are a means of delivering messages from teacher to student so they must be compiled by experts so that they are in accordance with the applicable curriculum (Adi, 2017: 28). This research was conducted by analysing the fourth grade English textbook of Elementary School (SD) published by Yudistira publisher. This textbook is used as one of the learning resources for English at one elementary school in Surakarta.

The scope of English subjects in SD / Ml includes limited oral communication skills in the context of the school, which includes aspects or language skills such as Listening, Reading, Speaking, and Writing. This statement is also written in Sutiyono (2014: 3) English learning in elementary schools is integrated with four language skills; namely listening, speaking, reading and writing. English in elementary schools in Surakarta are divided into local and extra-curricular content (Kaltsum and Utami, 2015:283)

\section{Local Content}

The implementation of a local content curriculum in the Indonesian education context is relatively new. The juridical foundation of the implementation of the local content curriculum refers to the Decree of the Minister of Education and Culture No. 0412 / U / 1987. As an elaboration, it was stated in the Decree of the Director General of Primary and Secondary Education Number 173 / -C / Decision / M / 1987. In its development later, the existence of local content is strengthened by the use of local content as one of the contents and structure of the curriculum that must be given at the primary and 
secondary levels. This is as stated in Article 37 of Law No. 20 of 2003 concerning the National Education System, which states that elementary and secondary schools consist of religious education subjects; citizenship education, language; mathematics; natural Sciences; Social Sciences; Art and culture; Physical Education and Sports; Skills / Vocational; and local content (National Education System Law No. 2002003 Article 37 paragraph 1).

Furthermore, in the Minister of National Education Regulation (Permendiknas) No. 22 of 2006 concerning content standards states that the Education Unit Level curriculum (KTSP) in addition to containing several subjects, there are also local content subjects that must be given at all levels of the education unit. Policies relating to the inclusion of local content subjects in the content standard are based on the fact that Indonesia, which consists of various ethnic groups that have multicultural diversity (customs, ordinances, language, arts, crafts, regional skills) is a characteristic that enriches the value of the life of the Indonesian people.

Nasir (2013: 3) writes that the local content curriculum is an educational program whose content and media and delivery strategies are linked to the physical environment, social environment, and cultural environment and regional needs." environmental sources close to the lives of students.

The local content of the physical environment is grouped into four, namely: (1) beaches, (2) lowlands, including watersheds, (3) highlands, (4) mountains or mountains. Local content of the social environment in the form of an environment that contains elements or social components that form a network of social interaction and can affect the attitude or actions of a person or group of people. The social components include community institutions and regulations that exist and apply in the area, where students and schools are located, such as villages, neighbourhood units, community units, village unit cooperatives, community health centre, integrated service community and others. Local content of the cultural environment discusses cultural issues. According to Koentjaraningrat culture is the whole system of ideas, actions and results of human work in the framework of community life that is made the self-belong of the community by learning. This statement is also written in Kaltsum and Hidayat (2018: 186). Based on several definition of culture, it can be concluded that culture is the set of learned values and way of life within members of a group and has three elements namely ideas, action, and human work or artefact.

Local content can be functioned as a vehicle for the development of national culture through regional culture, with an approach not to be an exclusive form of culture. The use of the physical, social and cultural environment can be used as media and learning 
resources. Selective and careful use of the environment can contribute greatly to the improvement of learning processes and outcomes.

From the description above, it can be concluded that local content is a curricular activity that develops competencies that are tailored to the characteristics and potential of the region, including the superiority of regions whose material cannot be grouped into existing subjects. Local content is an educational program that is content, media, delivery strategies related to the physical environment, social environment, and cultural environment as well as regional needs. Local content contains cultural characteristics, local social and environmental problems. This is in line with what has been written by Faridi (2010: 23) that is in the local content curriculum area, students are expected to be able to accommodate their sociocultural aspect of their environment. Based on the description above, this study limits its analysis to the local content of the physical environment, social environment, and cultural environment contained in the English elementary textbook. The conclusion about the local content aspect can be seen in Table 1.

TABLE 1: Local Content aspects.

\begin{tabular}{|c|c|c|}
\hline Components & Aspects & Elements \\
\hline \multirow[t]{3}{*}{ Local Contents } & Cultural aspect & Ideas, actions, human works or artefact \\
\hline & Social aspect & $\begin{array}{l}\text { community institutions and regulations that exist and } \\
\text { apply in the area, where students and schools are } \\
\text { located, such as villages, neighborhood units, } \\
\text { community units, village unit cooperatives, community } \\
\text { health centre, integrated service community and others }\end{array}$ \\
\hline & Physical aspect & $\begin{array}{l}\text { 1) beaches, ( } 2 \text { ) lowlands, including watersheds, ( } 3 \text { ) } \\
\text { highlands, (4) mountains or mountains. }\end{array}$ \\
\hline
\end{tabular}

\section{Method}

This research is qualitative research using content analysis approach particularly directed approach. In directed approach, analysis starts with a theory or relevant research findings as guidance for initial codes (Hshieh and Shannon, 2005: 1277). The subject of this research is English Textbook for elementary school grade $4^{\text {th }}$ and the object is the local content implied in the textbook. The data collecting addresses coding of analysis unit for each chapter. The focus of analysis unit is the local content which is spread in skills activities of Listening, Reading, Speaking, and Writing. The research instrument used is the content analysis sheet which is composed based on local content theory. The analysis data technique is based on Krippendorf analysis: unitizing, sampling, recording, reducing, inferring, and narrating. This study analysed the components based on the local content aspect which are physical, social, and 
cultural aspect as it has been stated previously, then figure out the scope of the aspect adapted from Hyundai (2013) written in Cahyati and Rahmijati (2017: 2). Wahyuni figures out the scope in two points traditional and modern, however this research figures out the scope into traditional and national.

\section{Finding and Discussions}

From table 1 above, it can be seen the description of the local content component that underlies the analysis. This study took an elementary school grade IV English textbook since the National Education Standards Board (BSNP) set the Basic Competency and Competency Standards, starting from fourth to sixth grade for the 2006 KTSP, and determine fourth grade with the aim of focusing analysis.

As explained above, this study uses a content analysis approach to one of the fourth grade English textbooks used in one elementary school in Surakarta, namely Muhammadiyah 3 Elementary School in Surakarta. The textbook is Basic English. New Edition. For Elementary School Year IV, the author of S.B. Sulaiman and Kenneth W. Ament, publisher of Yudistira, November 2016. Here are the description about the local content which can be found in each chapter. The book consists of fourteen chapters or Lessons

TABLE 2: Local Content Aspects found in the Textbook.

\begin{tabular}{|c|c|c|c|c|c|c|}
\hline Lesson & Materials & Activity & Page & $\begin{array}{l}\text { Aspect of } \\
\text { local content }\end{array}$ & Scope & $\begin{array}{l}\text { Additional } \\
\text { Information }\end{array}$ \\
\hline 1 & $\begin{array}{l}\text { My Friends } \\
\text { and I }\end{array}$ & Listening & 2 & $\begin{array}{l}\text { Physical } \\
\text { aspect }\end{array}$ & $\begin{array}{l}\text { National ( Jakarta, } \\
\text { Bandung) }\end{array}$ & $\begin{array}{l}\text { There are no local } \\
\text { content at all for } \\
\text { activities of } \\
\text { reading, writing } \\
\text { and speaking }\end{array}$ \\
\hline 2 & $\begin{array}{l}\text { Food and } \\
\text { Drinks }\end{array}$ & Writing, Speaking & 13 & $\begin{array}{l}\text { Physical } \\
\text { aspect }\end{array}$ & $\begin{array}{l}\text { National (Durian } \\
\text { Fruit) }\end{array}$ & $\begin{array}{l}\text { Most activities in } \\
\text { Listening, Reading } \\
\text { and speaking on } \\
\text { page } 13 \text { discuss } \\
\text { about western } \\
\text { food like burger } \\
\text { and sandwich. }\end{array}$ \\
\hline 3 & My Home & & & & & $\begin{array}{l}\text { All activities in } \\
\text { four skills (Listen- } \\
\text { ing,Reading, } \\
\text { Speaking, and } \\
\text { Writing do not } \\
\text { describe any of } \\
\text { local content } \\
\text { aspect }\end{array}$ \\
\hline
\end{tabular}




\begin{tabular}{|c|c|c|c|c|c|c|}
\hline Lesson & Materials & Activity & Page & $\begin{array}{l}\text { Aspect of } \\
\text { local content }\end{array}$ & Scope & $\begin{array}{l}\text { Additional } \\
\text { Information }\end{array}$ \\
\hline 4 & Times & & & & & $\begin{array}{l}\text { All activities in } \\
\text { four skills } \\
\text { (Listening, } \\
\text { Reading, } \\
\text { Speaking, and } \\
\text { Writing do not } \\
\text { describe any of } \\
\text { local content } \\
\text { aspect. }\end{array}$ \\
\hline 5 & $\begin{array}{l}\text { In the } \\
\text { School }\end{array}$ & $\begin{array}{l}\text { Introduction on } \\
\text { page } 33 \text {, Writing } \\
\text { on page } 36\end{array}$ & 33,36 & $\begin{array}{l}\text { Social } \\
\text { aspect }\end{array}$ & $\begin{array}{l}\text { National (picture } \\
\text { of Indonesian } \\
\text { National Flag, the } \\
\text { word of } \\
\text { Indonesian } \\
\text { Currency, Rupiah) }\end{array}$ & $\begin{array}{l}\text { Activities of } \\
\text { Listening, } \\
\text { Speaking, and } \\
\text { Reading do not } \\
\text { show any local } \\
\text { content }\end{array}$ \\
\hline 6 & $\begin{array}{l}\text { It Looks } \\
\text { Good }\end{array}$ & $\begin{array}{l}\text { Introduction on } \\
\text { page } 41\end{array}$ & 41 & $\begin{array}{l}\text { Cultural } \\
\text { Aspect }\end{array}$ & $\begin{array}{l}\text { Traditional } \\
\text { (Musical tool flute) }\end{array}$ & $\begin{array}{l}\text { All activities in } \\
\text { four skills } \\
\text { (Listening, } \\
\text { Reading, } \\
\text { Speaking, and } \\
\text { Writing do not } \\
\text { describe any of } \\
\text { local content } \\
\text { aspect. }\end{array}$ \\
\hline 7 & Hobbies & & 49 & & & $\begin{array}{l}\text { All activities in } \\
\text { four skills } \\
\text { (Listening, } \\
\text { Reading, } \\
\text { Speaking, and } \\
\text { Writing do not } \\
\text { describe any of } \\
\text { local content } \\
\text { aspect. }\end{array}$ \\
\hline 8 & $\begin{array}{l}\text { On the } \\
\text { Street }\end{array}$ & & 61 & & & $\begin{array}{l}\text { All activities in } \\
\text { four skills } \\
\text { (Listening, } \\
\text { Reading, } \\
\text { Speaking, and } \\
\text { Writing do not } \\
\text { describe any of } \\
\text { local content } \\
\text { aspect. }\end{array}$ \\
\hline 9 & $\begin{array}{l}\text { At the } \\
\text { Hospital }\end{array}$ & & 69 & & & $\begin{array}{l}\text { All activities in } \\
\text { four skills } \\
\text { (Listening, } \\
\text { Reading, } \\
\text { Speaking, and } \\
\text { Writing do not } \\
\text { describe any of } \\
\text { local content } \\
\text { aspect. }\end{array}$ \\
\hline 10 & $\begin{array}{l}\text { Daily } \\
\text { Needs }\end{array}$ & Writing & 79 & $\begin{array}{l}\text { Cultural } \\
\text { aspect }\end{array}$ & $\begin{array}{l}\text { National (rice is } \\
\text { Indonesian staple } \\
\text { food) }\end{array}$ & $\begin{array}{l}\text { Activities in } \\
\text { Listening, Readin } \\
\text { and Speaking do } \\
\text { not describe any } \\
\text { of local content } \\
\text { aspect. }\end{array}$ \\
\hline
\end{tabular}




\begin{tabular}{|c|c|c|c|c|c|c|}
\hline Lesson & Materials & Activity & Page & $\begin{array}{l}\text { Aspect of } \\
\text { local content }\end{array}$ & Scope & $\begin{array}{l}\text { Additional } \\
\text { Information }\end{array}$ \\
\hline 11 & $\begin{array}{l}\text { People } \\
\text { and } \\
\text { Things }\end{array}$ & & 85 & & & $\begin{array}{l}\text { All activities in } \\
\text { four skills } \\
\text { (Listening, } \\
\text { Reading, } \\
\text { Speaking, and } \\
\text { Writing do not } \\
\text { describe any of } \\
\text { local content } \\
\text { aspect. }\end{array}$ \\
\hline 12 & Activities & Reading & 96 & $\begin{array}{l}\text { Cultural } \\
\text { aspect }\end{array}$ & $\begin{array}{l}\text { National (rice is } \\
\text { Indonesian staple } \\
\text { food) }\end{array}$ & $\begin{array}{l}\text { Activities in } \\
\text { Listening, Writing, } \\
\text { and Speaking do } \\
\text { not describe any } \\
\text { of local content } \\
\text { aspect. }\end{array}$ \\
\hline 13 & Animals & & 101 & & & $\begin{array}{l}\text { All activities in } \\
\text { four skills } \\
\text { (Listening, } \\
\text { Reading, } \\
\text { Speaking, and } \\
\text { Writing do not } \\
\text { describe any of } \\
\text { local content } \\
\text { aspect. }\end{array}$ \\
\hline 14 & $\begin{array}{l}\text { Past } \\
\text { Activities }\end{array}$ & $\begin{array}{l}\text { Writing on page } \\
111 \text {, Speaking on } \\
\text { page } 114\end{array}$ & 111,114 & $\begin{array}{l}\text { Social and } \\
\text { cultural } \\
\text { aspect }\end{array}$ & $\begin{array}{l}\text { National (picture } \\
\text { of Indonesian } \\
\text { National Flag on } \\
\text { page } 111 \text { and on } \\
\text { page } 114 \text {, it } \\
\text { mentions about } \\
\text { bahasa) }\end{array}$ & $\begin{array}{l}\text { Activities of } \\
\text { Listening and } \\
\text { Reading do not } \\
\text { show any of local } \\
\text { content aspect }\end{array}$ \\
\hline
\end{tabular}

Based on the table information, we can say that most chapter on this textbook is less of local content, for example, we are able to see it from first, Lesson 1, My Friends and I. In this chapter, there are no local content at all for activities of reading, writing and speaking except in Listening which mentions about national local content, but not traditional one. The Listening skill on page 2 mentions about Jakarta and Bandung, where both are name of cities in Indonesia but not cities around Surakarta district.

Second, Lesson 2, Food and Drinks. Lesson Food and Drinks mentions physical local content on page 13, exactly, it mentions about tropical fruit from Indonesia, Durian. We can find Durian fruit almost in any district of Indonesia so it is a common and familiar tropical fruit which grows in all area of Indonesia, that is why, it is national local content and not traditional local content. Although this Lesson mentions about tropical fruit, Durian, most activities in Listening, Reading and Speaking merely discuss about western food like burger and sandwich.

Next are Lesson 3 My Home, Lesson 4 Time, Lesson 7 Hobbies, Lesson 8 On the Street, Lesson 9 At the Hospital, Lesson 11 People and Things,and Lesson 13, Animals. 
The Lessons mentions previously do not conveys any local content in all activities of Listening, Reading, Speaking, and Writing.

Lesson 5, In the School covers about social aspect of national local content. This lesson describes pictures of Indonesian National flag and mention a little about Indonesian currency, Rupiah. However, activities of Listening, Speaking, and Reading do not show any local content at all.

In Lesson 6, It Looks Good, we can find a picture of traditional scope of cultural local content, a flute in the introduction on page 41 . Flute is traditional musical tool from Java, but not limited in Surakarta. However, all activities in four skills (Listening, Reading, Speaking, and Writing do not describe any of local content aspect at all.

Lesson 10, Daily Needs, on Writing skill aspect page 79, mentions about cultural aspect of national local content,rice. It is categorized as local content since Indonesian staple food is rice. However, activities in Listening, Reading and Speaking do not describe any of local content aspect at all.

Next in Lesson 12, Activities, we can find national scope of cultural local content, rice, in writing activities page 96, as we know, rice is nationally Indonesian staple food. However, activities in Listening, Writing, and Speaking do not describe any of local content aspect at all.

The last, Lesson 14, Past Activities, the social local content of national scope is found at Writing on page 111 and Speaking on page 114, exactly about picture of Indonesian National Flag on page 111. In additional, on page 114, mentions about bahasa means bahasa Indonesia however activities of Listening and Reading do not show any of local content aspect.

After reading and doing analysis, the textbook contains fourteen chapters. Each chapter consists of four skills, Listening, Reading, Speaking, and Writing, totally we can find fifty six skills which is divided into 14 topics of Listening skills, 14 topics of Reading skills, 14 topics of Speaking skills and 14 topics of Writing skills. However, the local content is not spread in all skills from these 56 skills and can only be found in 8 skills from total 56 skills, or it is about $14 \%$.

This textbook covers four language skills, Listening, Reading, Speaking, and Writing, therefore it is like what has been stated previously that English Language is divided into four skills, in Sutiyono (2014: 3). There are 14 Chapters or Lessons, each chapter discusses aboout activities of Listening, Reading, Speaking, and Writing, therefore we can find 56 activities totally in all four languane skills. However, the local content aspects are only found in 8 skills from total 56 skilss or $14 \%$, means that the local content aspects are not until $50 \%$ even worse, only $14 \%$. This is supported by Sutiyono's research that is 
based on the overall evaluation of English books for elementary schools, only 30\% are categorized as good. Categories are seen from the suitability of the material with the curriculum objectives and characteristics of early age learners. The differences of this research with the former is this research focuses on local content aspect, and the former focuses on the elaboration of materials.

\section{Conclusion}

English for elementary school is categorized as local content curriculum area means the material should cover about the distinctive aspect where English is learned. Besides, it also covers about the physical, cultural, and social aspect where English is learned. After analysing one English textbook used in one elementray school in Surakarta, it is found that the book is lack of local content, precisely $14 \%$. These $14 \%$ of local content is about national local content. The conclusion is that government policy that sets English as a local content has not gone well, seen from the aspect of the textbook used or as a learning resource.

\section{Suggestion}

Based on the findings, we can conlude that English as a local content curriculum area as not gone well, one of them can be seen from the textbook used. According to the researcher, English should not be as a local content but as a mandatory content given that learning English will be more relevant if faced with the need for real and practical language use, one of which is an international communication tool.

\section{References}

[1] Adi, Y.K.(2017). Analisis Muatan Pendidikan Karakter Dalam Buku Teks Kurikulum 2013 Kelas III SD Semester 1, Profesi Pendidikan Dasar Vol. 4 No. 1, Juli 2017 http: //journals.ums.ac.id/index.php/ppd/article/view/3754/3447

[2] Cahyati, S.S, \& Rahmijati, C. (2017). Exploring Local Values and Culture in English Textbook. Lingual Vol.9, No.2, 2017 https://ojs.unud.ac.id/index.php/languange/ article/view/35621/21479

[3] Faridi, A.(2010). The Development of Context-Based English Learning Resources for Elementary Schools in Central Java. https://www. 
researchgate.net/publication/50316719_The_Development_of_Context-

Based_English_Learning_Resources_for_Elementary_Schools_in_Central_Java

[4] Hsieh, H.F., \& Shannon, S.E. (2005). Three approaches to qualitative content analysis. Qualitative health research, 15(9), 1277-1288. http://journals.sagepub.com/ doi/pdf/10.1177/1049732305276687

[5] Kaltsum, H.U, \& Hidayat, M.T. 2018. Child Friendly English Based On Cultural Local Content In Surakarta Proceeding of International Conference On Child-Friendly Education, Universitas Muhammadiyah Surakarta, April 21st-22nd, 2018 https://publikasiilmiah.ums.ac.id/bitstream/handle/11617/ 10058/ICCE\{\%\}20Proceeding\{\%]20FULL\{\%\}20rev06062018_32.pdf?sequence= 1\&isAllowed=y

[6] Nasir, M.(2013). Pengembangan Kurikulum Muatan Lokal Dalam Konteks Pendidikan Islam dii Madrasah, Hunafa: Jurnal Studia Islamika Vol. 10, No. 1, Juni 2013. https: //jurnalhunafa.org/index.php/hunafa/article/view/12/4 Permendikbud Tahun 2016 Nomor 008

[7] Sutiyono, A. (2014).Model Pengembangan Bahan Ajar Untuk Meningkatkan Keterampilan Berbicara Bahasa Inggris Siswa Sekolah Dasar Di Bandar Lampung Universitas Pendidikan Indonesia I Repository.Upi.Edu I Perpustakaan.Upi.Edu http: //repository.upi.edu/12603/4/D_PK_0907741_Chapter\{\%\}20\{\%\}281\{\%\}29.pdf 